\title{
節点解法による通気網解析の高速化について*
}

\author{
井上: 雅 厸 ${ }^{\prime}$ 内野 健 …2
}

[UDC 622.41]

\section{Speeding up of Node Potential Method for Ventilation Network Analysis}

\author{
by Masahiro INOUE ${ }^{1}$ and Kenichi UCHINO ${ }^{2}$
}

The authors have already proposed a practical node potential method for ventilation network analysis, which is today used in all major coal mines in Japan. However, in the course of experience with this method it was found that two major problems must be solved for the calculation to be sped up: converge retardation by inadequate selection of an initial value of pressure to be given to the nodes and by extraordinarily small resistances of airway.

The present paper describes the improved method by which the calculation time is reduced to about one second to one fourth of that by the previously proposed method, the new techniques being introduced to solve the above problems. Also, the effect of natural ventilation pressure on the forced ventilation system and a problem of ventilation control in emergency are discussed, using the newly proposed method.

[ $1 \sim 2$. Faculty of Engineering, Kyushu University.

\section{1. 緒}

\section{言}

通気網解析に用られる計算方法には, 大別するとメッシュ法 ${ }^{1) \sim 4)}$ と節点解法 ${ }^{5) ~ 9)}$ がある。両者の特徵については前報 ${ }^{7)}$ で述べたの で省略するが，節点解法は基礎理論が理解しやすいこと，プログ ラムが簡単であることなどの長所を有しており，実用上の観点か ら節点解法がメッシュ法に比較して，なお検討の余地があると考 えられるのは計算時間の問題のみであるといってよい。

従来，節点解法が実際にあまり用いられなかった大きな理由は， メッシュ法に較べて長い計算時間を要するということであったが， これは計算の基礎理論自体に本質的な原因があるためではなく， これまで, 計算の高速化のための研究が十分ではなかったためで ある。そこで，筆者らは節点解法の特徵を生かしながら計算時間 を短縮する方法を考案し, 前報 ${ }^{7)}$ で節点解法による通気網解析は 実用的に可能であることを示した。

計算時間は, 通気網の大きさやファンの数, 特性, 計算に使用 する定数の值, あるいは使用するコンピュータ等により㝜なるの で，一概に述べることは困難であるが，筆者らの方法で計算した 場合, 節点数が 100 , 坑道数が 150 程度のもので, 計算に必要な条 件を適当に与えると，およそ 2 分程度であった。ただし，コンピ ュータは 16 ビットパソコン( 数值演算プロセッサ使用)である。 この計算時間は従来のメッシュ法による計算に要した時間と比較 しても, 同程度であると考えられる。また, 大型計算機を用いた

* 1988 年 9 月 3 日受付 1989 年 4 月 25 日受理

1. 正会員 工博 九州大学助教授 工学部資源工学科

2. 正会員 工博 九州大学教授 工学部資源工学科
1. Assoc. Prof., Dr.
2. Prof., Dr.]

和解析以外の処理と平行して行なわれること が多いために, 15〜30分程度を要していたことを考慮すれば，こ の程度の計算時間であれば，実用的には計算時間による支障はな くなったと判断される。

以上の結果を踏まえて，筆者らはこの方法を用いて通気網解析 システムを開発した。これは, 実際の通気計算で必要なほとんど の条件を考慮することが可能であり, 通気網解析プログラムを核 として, データの入力からチェック, 計算結果の図面化までをシ ステム化したもので, 現在日本の主要炭鉱で用いられるまでに至 っている。

しかし，これまで本システムにより多くの鉱山の通気網解析を 行なった事例から, 計算実技上いくつかの改善すべき点ならびに 注意事項が浮かび上がってきた。その一つは, 節点の圧力に対し 不適当な初期值を用いた場合, 計算時間が必要以上に長くなると いうことである。また, 通気抵抗が特に小さい坑道が存在する通 気網では，計算時間が予想以上に長くなる傾向が見出された。

そこで, 本研究においては, 適切な初期值が不明の場合, ある いは通気網の特性がどのような場合であっても，特別の考虑を厸 うことなく短時間で収束することを主眼として, 種々の観点から 計算法の改良を行ない, 前報 ${ }^{7)}$ で示した方法のみを用いた場合に 較べて計算時間を $1 / 2 \sim 1 / 4$ 程度に短縮させることができた。本 論文ではこの検討結果と,この方法を用いた例として, これまで 無視されがちであったが, 通気網の構造によっては極めて重要な 因子となる自然通気圧の影響について検討した結果について述べ る。 


\section{2. 節 点解 法}

前報 7 で筆者らが提案した節点圧力を求めるための基本的な計 算式は次のようである。圧力を求める節点を $x$ とし, この節点 $x$ に坑道により接続している節点を $i$ とすれば, 節点 $x$ の圧力 $P_{x}$ は次式で計算される。

$$
\begin{aligned}
& P_{x}=\frac{\sum \frac{P_{i}}{K_{i x}}}{\Sigma \frac{1}{K_{i x}}} \\
& K_{i x}=\left(\left(\left|P_{i}-P_{x}\right|\right) R_{i x}\right)^{1 / 2}
\end{aligned}
$$

ここで, $P$ は圧力 $\left(\mathrm{kg} / \mathrm{m}^{2}(=\mathrm{mmAq})\right), R$ は坑道の比抵抗

(Weisbach) である。ただし，本式では記述を簡単にするために 節点間の高度差, 定流風道, ファンの風量等を省いている。 $\mathrm{Kix}$ は圧力損失と風量の関係を線形化するための擬似的な通気抵抗と 考えることができる。

本式からわかるように，本節点解法は簡単な関係を用いて通気 網の各節点の圧力を求める方法である。しかしながら，本式をそ のまま用いたのでは計算時間が長くかかるので，筆者らはこの式 を基本にして, 計算を短時間で終了させるために加速係数の使用, あるいは近似式ではあるが計算時間がかなり短い簡易型の高速計 算式の使用等のいくつかの方法を提案した ${ }^{7)}$ 。なお, 実際のプログ ラム中では(1)式は次式のように変形して用い, 計算精度の低下を 防いでいる。ただし，右辺の $P_{x}$ は本計算実施前の $P_{x}$ である。

$$
P_{x}=P_{x}+\frac{\Sigma \frac{P_{i}-P_{x}}{K_{i x}}}{\Sigma \frac{1}{K_{i x}}}
$$

この方法のように節点圧力を逐次的に修正していく方法では, 王力を求めるべき全ての節点の圧力を上式で計算し補正する。本 論文ではこれを計算の 1 サイクルと呼び，この補正值を圧力補正 值と呼ぶことにする。このとき，計算の 1 サイクルにおける最大 の圧力補正値があらかじめ設定した許容值以下になった場合に計 算は収束したとして終了する。

Bhamidipati ${ }^{8)}$ 等は, 筆者らと同様に圧力損失と風量の関係 を修正係数（本論文 $K_{i x}$ に相当する）を用いて 1 次式の関係に直 して, 通気網解析を行なら方法を発表している。同論文ではメッ シュ法および節点解法に対する方法が述べられているが，いずれ もマトリクスを用いる方法であり，このために必要なコンピュー タのメモリが筆者らの方法に較べてかなり多いので, パソコンで の処理にはあまり向かないという久点がある。また, 自然通気圧 やファンの取扱に関する方法が示されていないので, この意味か らも実用的な観点からすれば不十分である。なお，同論文には16 節点 26 坑道の通気網の場合, メッシュ法と節点解法に計算時間の 差はあまりないこと,プログラムの作成は節点解法のほうが簡単 であること等が述べられている。

佐々木ら ${ }^{9)}$ は，明らかに異なった節点圧力の逐次計算法として 節点圧力の計算式 ( 同論文(6)式 ) を示している。しかしながら, 同論文で示された式は筆者らが示した節点圧力を求める方法で加 速係数を 2 とした場合の式と全く同じである。これは次のように して簡単に証明される。

同論文の変数をそのまま使用し, $\delta_{x j}$ および $\left|P_{x}{ }^{n}-P_{j}\right|$ の值を 場合にわけて吟味すれば

$$
\begin{aligned}
& \delta_{x j}\left|P_{x}{ }^{n}-P_{j}\right|=P_{x}^{n}-P_{j} \\
& K_{j x}=\left|P_{x}{ }^{n}-P_{j}\right|^{1 / 2} R_{x j}{ }^{1 / 2}
\end{aligned}
$$$$
\text { であり, }
$$

となるので，同論文(6)式は次のようにな。

$$
P_{x}{ }^{n+1}=P_{x}{ }^{n}+2\left\{\left(\frac{\Sigma \frac{P_{j}}{K_{j x}}}{\Sigma \frac{1}{K_{j x}}}\right)-P_{x}{ }^{n}\right\}
$$

上式の( )内の式はまさに筆者らによって導かれた(1)式であり，上 式で得られる圧力は筆者らの提案した方法で加速係数を 2 とした 場合に他ならない。この意味で佐々木らの計算式は新しい方法と は言えない。

\section{3. 初 期 值}

逐次的に節点圧力を修正する計算方法の場合，圧力を固定する 節点付近の節点は比較的早く最終的な圧力の值に近くなるが，圧 力を固定する節点から遠く離れている節点はなかなか最終的な値 に近づかないので，そのような節点が最終的に近づくような值を 初期值として用いれば，計算が早く終了するようになることは容 易に賏像される。

図 1 および図 2 はそれぞれ図 3 および図 4 に示す通気網におい て, 圧力を固定する節点以外の全ての節点に同じ初期值を与えた

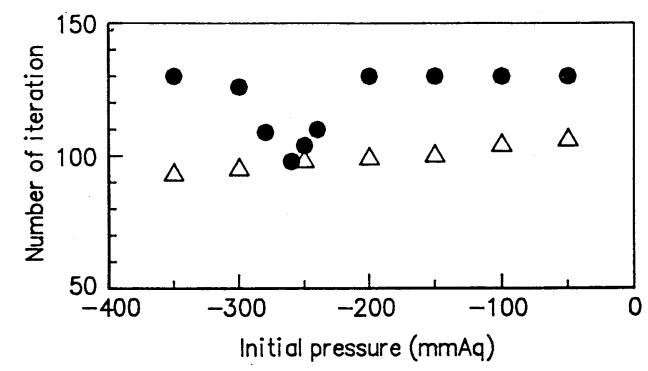

図 1 図 3 の通気網が収束するまでの反復回数

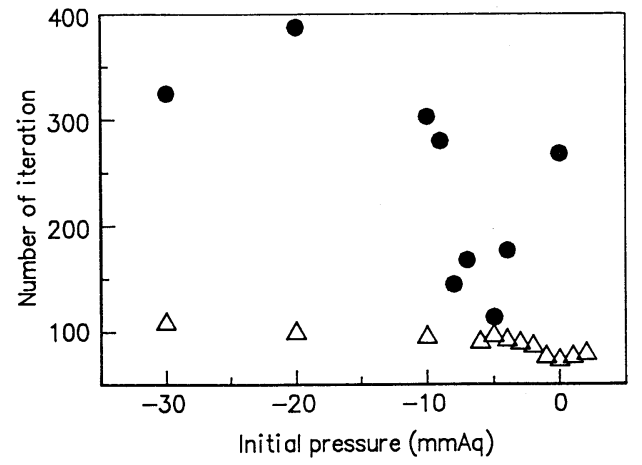

図 2 図 4 の通気網が収束するまでの反復回数

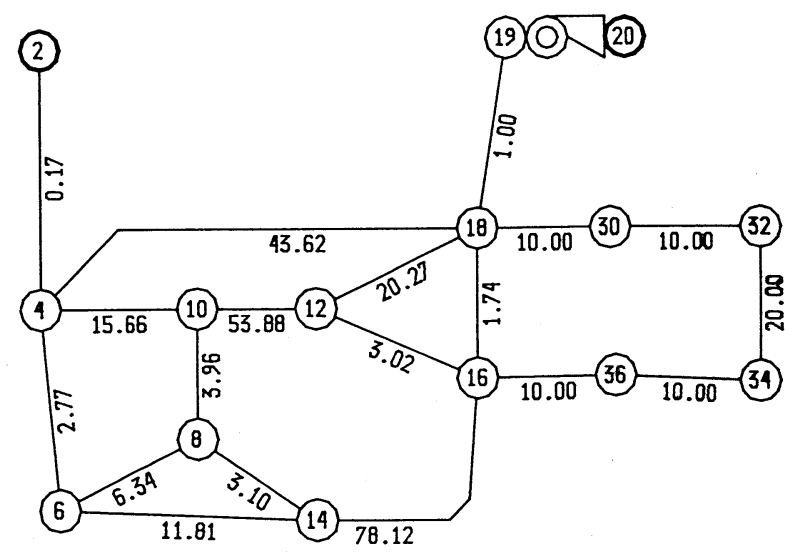

図 3 図 1 の反復回数の検討に用いた通気網 （線の下の数字は通気抵抗（ミュルグ）） 


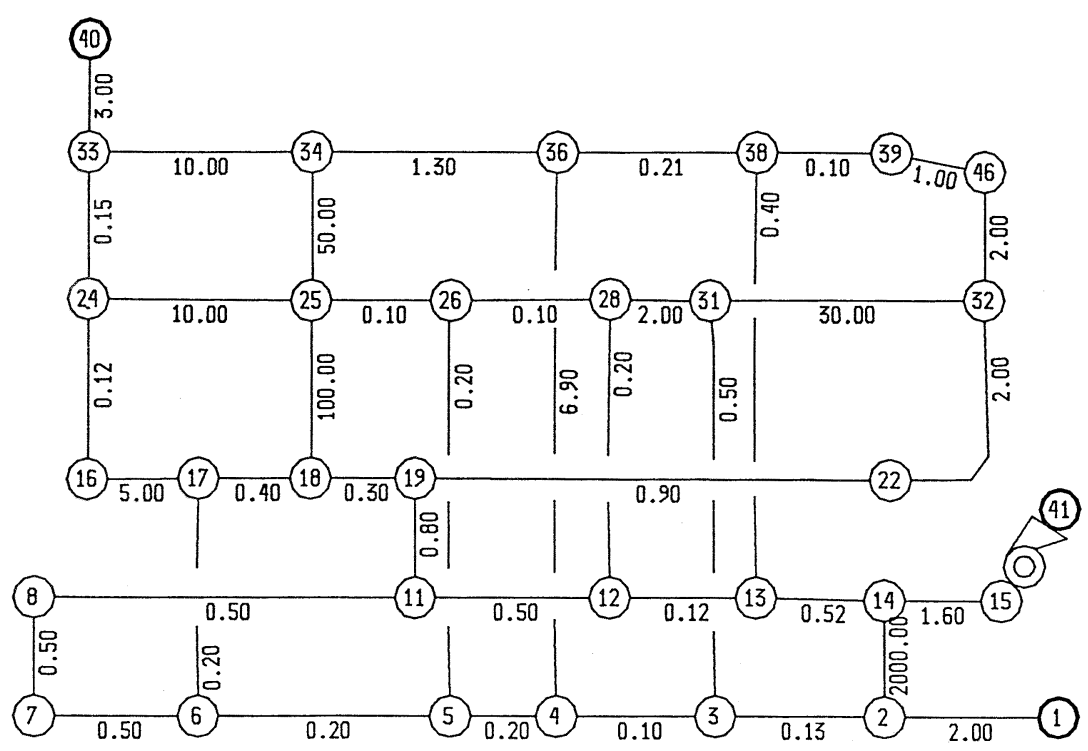

図 4 図 2 の反復回数の検討に用いた通気網（線の下の数字は通気抵抗（ミュルグ））

場合に，その值により収束するまでの反復回数（計算が収束する までのサイクル数 ) がどのように変化するかを示したものである。 同図中の黒丸で示したものが前報 ${ }^{7)}$ で述べた方法のみを用いたも のである。三角形で示されるものが本節および次節で述べる方法 を併用したものであり, そのほかの条件は同じである。これらの 計算においては，前報で述べたように収束がある程度進んだ状態 では簡易型の高速計算を併用しているので, 反復回数と計算時間 とは正比例するわけではないが，ほぼ比例すると考えてよい。

同図から，前報で述べた方法のみを用いた場合，与える初期值 により収束するまでの反復回数が大きく異なることが明瞭である。 特に, 通気網が大きい図 2 の場合は, この差が大きく 4 倍以上の 開きがある。通気網が小さい図 1 の場合は, ファンの特性が収束 に比較的大きな影響を与え, このため, 初期值の影響が比較的小 さくなったものと考えられる。短時間で計算が収束する初期值の 範囲は比較的狭いので, 適当な初期値を予測することは困難であ ることがわかる。これに対して今回述べる方法を併用すれば, 初 期值にはほとんど関係なくしかも反復回数が少ないことがわかる。

与えた初期值が適当であるかどうか, あるいは高すぎたのか低 すぎたのかは，圧力補正值を見ていれば判断できる。一般に圧力 計算の初期では最大の圧力補正值が生じる節点はさまざまである が, 計算の後期ではほとんど同じ節点で生じ, 大きさは徐々に小 さくなるが同じ符号である。この值が正であれば，与えた初期値 が小さすぎたのであり，次の計算ではより大きな初期值を与える と計算はより速く収束する。逆にこの值が負であれば与えた初期 值が大きすぎたのであり, 次の計算ではより小さな初期值を与え るとよい。解析を行なう度に初期值を修正すれば, 徐々に最適な 初期值を得ることができるようになる。しかしながら, 通気網を 変更した場合には, 最適な初期值は異なるのが普通であり, 全く 初期值が不明の場合よりは無駄が少ないものの, 同様の作業を繰 り返すことになる。

初期値が最適な值から大きく異なる場合には，1 サイクルあた りの圧力補正值はあまり大きくないにもかかわらず，この補正值 がいつまでも許容值以下にならない計算状態が続く。従って, こ れが原因による計算時間の消費を防ぐために次のようにして全体 の傾向を補正する計算を行なう。すなわち, 圧力計算を 1 サイク ル行なうと, 全ての節点の圧力が補正されるが, この補正值の平 均值を求め, 圧力計算の 1 サイクルが終了した後, この平均值の
数倍を全体の補正値として, 圧力を固定する節点を除く全ての節 点に加えるのである。このようにすると全体的な圧力をより速く 最終的な值に近づけることができる。本論文の解析では平均值の 4 倍程度を 1 サイクルの計算終了後加えることにした。ただし, 平均值の符号が前回の平均值と逆の場合にはそのまま用い, 収束 が進み, この全体的な補正值がある程度小さくなるとこの操作は 行なわない。この 4 倍という值は, これをあまり大きくすると発 散の可能性があるので, この程度の值を用いている。

この方法では傾向が反対の節点も同じ処理を行なうことになる が, 最適ではない初期值を使用したことによる計算時間の無駄を 減少することができる。この結果, 初期值にあまり注意を払わな くても, 反復回数が増加する程度が減少したので, 初期值の值は 次のように算出することにより, 通気網解析を行なう者が考慮す る必要がないようにした。すなわち, 初期值としては各坑口の圧 力の平均值を用いるのである。ただし, ファンがある坑口は, フ フンより坑内側の節点の圧力を用いる。また, 高度差があれば当 然であるがその分の圧力を各節点に補正する。

\section{4. $K_{i x}$ の值について}

圧力計算を行なう場合, 圧力の計算結果は直ちにその節点の王 カとし，他の節点の計算に用いる。この圧力計算に用いる $K_{i x}$ の 計算式の中には圧力が含まれているが，この圧力としては，1 サ イクル内の圧力計算で新しく求められた圧力を直ちに使用するの は望ましくない結果を与える。その理由は，このようにすると坑 道で接続される一組の節点の圧力計算において, 一方の節点圧力 を求めるために使用した $K_{i x}$ と他方の節点圧力を求めるために使 用した $K_{i x}$ とが異なるようになるからである。特に通気抵抗が小 さい場合， $K_{i x}$ の值が大きく変化することになる。従って, $K_{i x}$ の值は 1 サイクルの計算においては一定の值としておくのがよい。

本節之前節の方法は極めて簡単であるが, 図 1 および図 2 に示 すように, 反復回数を減少させる効果がある。

\section{5. 変数の精度}

節点解法による通気網解析は, 通気網内の各坑道の抵抗值が 1 ミュルグ程度以上であり, どの坑道にも数十 $\mathrm{m}^{3} / \mathrm{min}$ 以上の風量 が流れるような場合には比較的早く収束する。すなわち，各節点 間の圧力差があまり小さくならないような条件であれば, 収束が 
早い。しかしながら，通気網解析の目的を考えると，通気遮断の シミュレーションを行なう場合のように，極めて僅かの風量しか 流れないような坑道が存在する場合の解析を行なうことも考えら れる。

まず，通気網解析において，圧力の值としてはどの程度まで小 さな值を取り扱う必要があるのかについて考える。任意の坑道で 生じる圧力損失は一般に次式で与えられる。

$$
P=R Q^{2}=0.001 \mathrm{r}(\mathrm{q} / 60)^{2}
$$

この式から単位風量変化した場合の, 坑道の圧力損失の变化は次 式のようになる。

$$
d P / d q=5.6 \times 10^{-7} r q
$$

本式は，通常日本の鉱山で使用している単位で表わしており，r はミュルグ単位の通気抵抗, $q$ は $\mathrm{m}^{3} / \mathrm{m}$ in 単位の風量である。

例えば，通気抵抗が 0.1 ミュルグである坑道を考える。この坑 道を流れる風量が $600 \mathrm{~m}^{3} / \mathrm{min}$ の場合にその坑道に発生する圧力 損失は， $0.01 \mathrm{~mm} \mathrm{Aq}$ である。この風量が $1 \mathrm{~m}^{3} / \mathrm{min}$ 変化した場合の 圧力損失の変化は $3.3 \times 10^{-5} \mathrm{mmA} q$ である。この坑道を流れる風 量が 60 および $6 \mathrm{~m}^{3} / \mathrm{min}$ の場合には圧力損失の変化はそれぞれ $3.3 \times 10^{-6}$ および $3.3 \times 10^{-7} \mathrm{mmA} q$ となる。このように風量が少 ない条件でも正1,く風量を求めるためには, 計算ではこの值より も小さな值を取り扱う必要がある。また，収束の許容値を与える 場合にもこのことを考慮して与える必要がある。

このような状況は例えば次のような場合に生じる。すなおち， 本来は 1 本の坑道を直列な 2 本以上の坑道に分割し,一つの坑道 の通気抵抗を大きくし, 残りの坑道の通気抵抗を小さくすると, 風量は小さいが抵抗の小さな坑道が生じる。また，圧力損失の計 算には(6)式の Kixを用いるが, 同式からわかるように, 圧力差が 小さいと小さな䛊差によるKixの変化が大きくなり，しかもこれ は逆数の形で使用するので, 計算が収束しにくくなる原因の一つ となる。

次にどの程度大きな值が必要であるかを考えると，圧力の值は ファンの負圧だけであれば, 通常 $500 \mathrm{mmAq}$ 以下の值であるが, 深度を考慮すると $1000 \mathrm{mmAq}$ 程度の值になる。従って, 有効桁 数が 10 析程度は必要であるということになる。コンピュータで用 いる変数は単精度の場合 4 バイト型であり, 7 桁の精度がないの で, これでは有効数字が不足することになる。従って, 倍精度の 8 バイト型を用いる必要がある。圧力値に倍精度を使用してもそ の他の計算は単精度で行なうことができるので, 計算速度の低下 はほとんどない。有効数字が不足している場合, どんなに計算を 長時間行なっても, 圧力補正值があらかじめ収束条件として設定 した許容值以下にならないことがある。また, この限界付近では, 収束するまでの計算時間が極めて長くなり，無䭾に計算を行なう ことになる。

節点解法は, 圧力を最初に求める方法であるから, 各節点にお ける風量のバランスを厳密に0になるようにすることは基本的に 困難である。すなわち, 圧力が $10^{-5} \mathrm{~mm} \mathrm{Aq}$ まで正しく求められて いるとしても，節点間の圧力差が小さい場合には, $1 \mathrm{~m}^{3} / \mathrm{min}$ 程 度の風量を正しくバランスさせるためには, これ以下の圧力が正 しく求められていることが必要なことがある。メッシュ法は風量 を最初に求める方法であり, 風量に関しては原理的にどの節点に おいてもその代数和は 0 になるように方程式を作成するので，こ の問題は生じない。メッシュ法によって計算された風量から圧力 を求める場合には, 圧力を求める坑道の経路によって, 圧力は多 少異なるのが普通である。節点解法の場合には, 節点圧力を最初 に求める未知数にしているので, この問題は生じない。

\section{6. ファンの特性曲線}

筆者らは, ファンの特性曲線の考慮方法として, ファンが設置 された部分を流れる風量と圧力損失には 2 次関数の関係があると 仮定し, この関数を求め, この関数とファンの特性曲線の交点を 次の予測值とすることを提案した ${ }^{7)}$ 。この関数を平松 ${ }^{10)}$ は坑内の 抵抗曲線とよび, Hartman ${ }^{11}$ ) は鉱山特性 (Mine characteristic）とよんでおり，統一されていないが，ここでは鉱山特性とい う用語を用いることにする。この関数が必ず原点を通ると考えら れるならば，与えたファンの予想風量とこの両端の節点の圧力と からこの関数は直ちに求められる。しかしながら, 実際にはこの 関数は必ずしも原点を通らない。すなわち, 坑内に自然通気圧や, 他のファンが存在する場合には原点を通らない。ファンを停止し ても通気が流れるのはこの一例である。この原点からのずれは, 主要扇風機 (以下主扇と記す) の動作点を予測する場合にはほと んど問題とならないが, 補助扇風機 (以下補扇と記す) の場合に は問題となることがある。

主扇によって既に通気が流れている方に補扇を設置し，この 補扇の能力がこの風量以下であった場合を考える。この状態では 補扇の最大風量を越えて通気が流れることになり，補扇をはさむ 節点の圧力は通気が流れる方向に低下することになる。このよう な場合，風量と圧力損失との関数が原点を通ると仮定すると，こ の関数は第 5 図の破線で示すように下向きの放物線になり，実際 にはありえないものになる。

これは次のようにして解決することができる。すなわち，ここ を遮断し通気が全く流れないようにした場合を考えると，ここに はある圧力差が生じている。従って, この関数は図 5 の実線で示 すように，風量 0 においてこの圧力を通るとすればよい。この大 きさを予測することは困難であり，正負さえ予測できない場合も ある。しかし，この值が最終結果に影響を与えることはないので， 計算が不能にならないように，負の大きめの值を使用するとよい。 また，このような可能性があるファンに対しては，図 5 一点鎖線 で示すように特性曲線のデータも延長して入力し, 圧力が負の值 をとってもよいようにしておく必要がある。

以上はファンの動作点について述べたが，このようにして求め られる予想風量をそのまま次のファンの風量として代入すると, 収束が早くなるとは限らない。すなわち，1 サイクルの圧力計算 では，節点の圧力が直ちに新しい風量に対応する圧力にはならな い，換言すれば節点圧力の反応が遅れるからである。従って，次 の圧力計算に与えるファンの風量を現在の風量と上記の方法で求 められた風量の間にとるほうが計算が安定し, 結局, 早く収束す ることになる。このようにしてもかなりの繰り返しを行なうので，

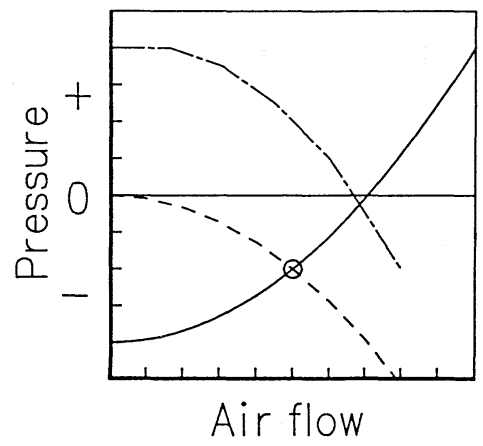

一点鎖線：ファンの特性曲線, 破線：解析不可 能な鉱山特性, 実線：解析可能な鉱山特性 図 5 圧力が負となる鉱山特性の取扱 


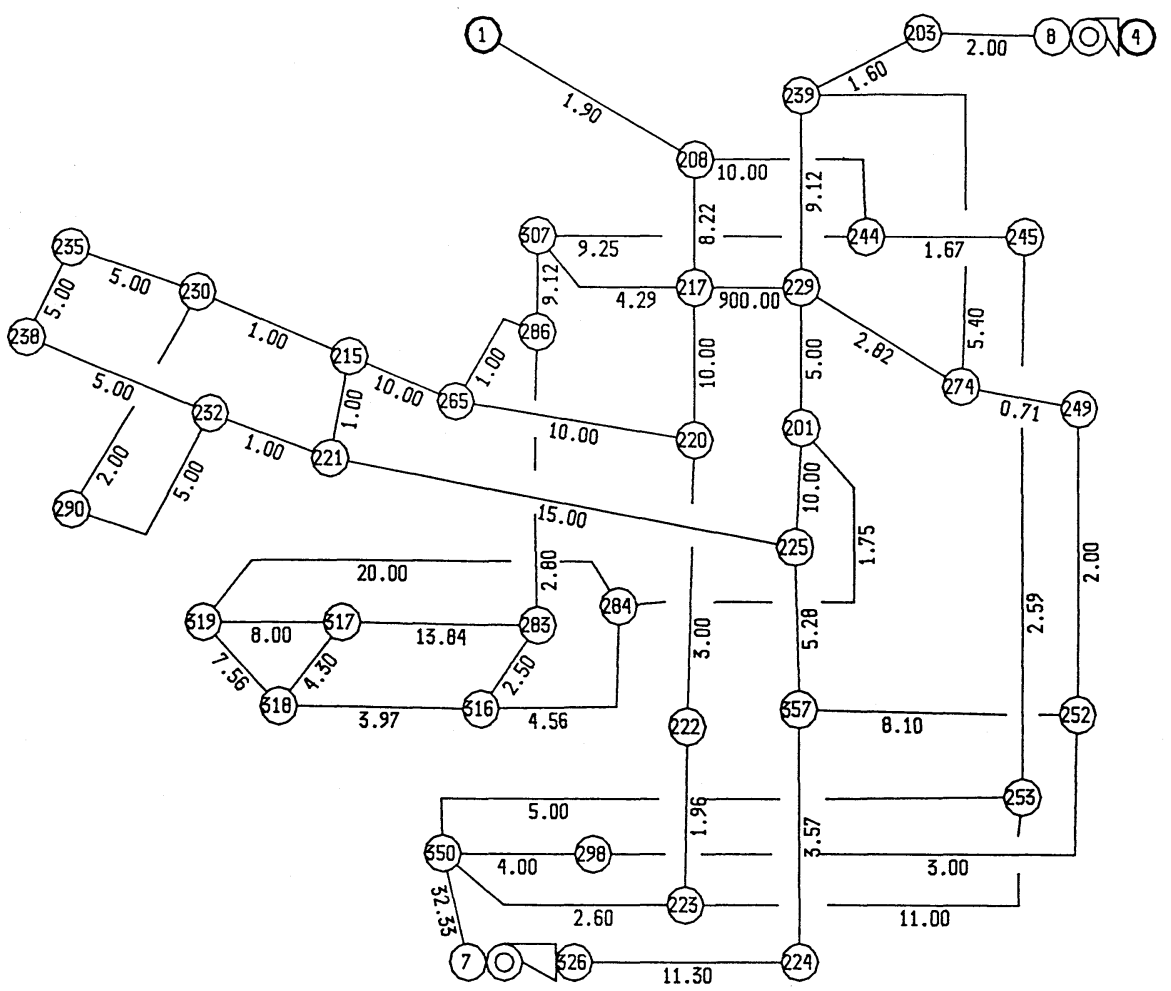

図6 通気網の例 (線の下の数字は通気抵抗 (ミュルグ ) )

表 1 計算順序と反復回数

\begin{tabular}{|c|c|c|c|c|}
\hline \multirow{5}{*}{ 計算順序 } & \multicolumn{4}{|c|}{ 反復 回 数 } \\
\hline & 図 3 & 図 4 & 図 6 & 図 6 \\
\hline & & & （補扇有） & （補扇無） \\
\hline & 節点数 15 & 節点数 32 & 節点数 41 & 節点数 41 \\
\hline & 坑道数 19 & 坑道数 41 & 坑道数 53 & 坑道数53 \\
\hline 1 & 99 & 138 & 373 & 255 \\
\hline 2 & 99 & 111 & 381 & 324 \\
\hline 3 & 98 & 92 & 369 & 245 \\
\hline
\end{tabular}

ファンの特性は十分な精度で考慮される。

\section{7. 計 算 順 序}

圧力の計算を行なう順序が収束に与える影響を検討するために， 次のように計算の順序を変えて通気網計算を行なった。

1. 与えたデータの順番

2. 圧力固定節点に近い方から行なう

3.ファン(主扇)に近い方から行なう

与えたデータの順番とは節点番号の小さい順のことであり, 順番 に関しては特に考慮しないことを意味する。対象とした通気網は 図3，図4 および図 6に示すようなものであり，図6 の場合は補 扇を考虑した場合と, 補扇をなくし, その間を通気抵抗が 1 ミュ ルグの坑道で接続した場合の 2 種類を行なった。压力変化の許容 值を $0.0001 \mathrm{mmAq}$ とした場合に, 計算が収束するまでの反復回数 を表 1 に示す。

これらの中で反復回数が最も少ないのは 3 の場合であるが, 同 表からわかるように，ほとんど差がない場合もある。すなわち， ファンの影響が相対的に大きいと考えられる図 3 および図 6 で示 すように補扇が存在する場合には, ほとんど羑がない。また， 1 と 2 では反復回数が少ない順序が逆になる゙ことがある。これらよ り更に大きな通気網 (節点数 131 , 坑道数 $207 お よ ひ ゙$ 節点数 174 , 坑道数 272 ) で同様の検討を行なったが, ほとんど差が認められ なかった。計算順序の変更は比較的プログラムが面倒である反面,
必ず反復回数を減少できるわけではないので, 全体的に効果が小 さいと判断される。

通気網を变更した場所が 1 箇所であり，既に計算された圧力分 布を用いてこれを初期值にする場合には，この変更された部分か ら計算を行なうことも考えられる。こうすると反復回数が減少す ることが多い（ 1 2 割程度 ) が，データを毎回変更する手間と 時間を考えるとあまり得策ではない。

\section{8. 加 速 係 数}

加速係数は一般に計算が発散しないならば, 大きいほど収束は 速い。節点数が少なく，坑口の圧力を固定しているような場合に は, 2 から 2.5 程度までの值を使用しても発散せず，加速係数を使 用しない場合に較べて短時間で計算が終了することがある。しか しながら，筆者らの行なったいくつかの実際の鉱山の解析では， 2 以上の值を用いると発散の可能性が生じ，まれではあるが 1.8 でも発散することがある。このような場合には多くはファンの特 性や与えた初期值の影響も絡んでいるので, 加速係数の值だけで. 論ずることはできないが，多少安全側に考え，解析が発散して無 䭾な計算時間を費やすよりはある程度小さめの値を用いる方がよ いと考えられる。従って，筆者らは標準的な加速係数の値として， 圧力計算の初期には 1.6 ，その後 1.8 を用いることにしている。

また加速係数が大きいと発散はしないが，圧力補正值がある程 度小さくなった後なかなか収束しないことがある。これは, 発散 の一歩手前の状況であり，収束を速めるための係数が逆に作用し ている。このような場合には加速係数を 0.2 程度小さくするだけ で収束することが多い。

\section{9. 自然通気圧の影零}

強制通気の行なわれるところでは，自然通気圧の影響は無視で きる程度に小さいというのが，教科書の説くところであるが，こ れは主扇の発生圧力に対し，相対的に自然通気圧が小さいという ことである。坑内の局所的な通気回路についてみると，むしろ， 


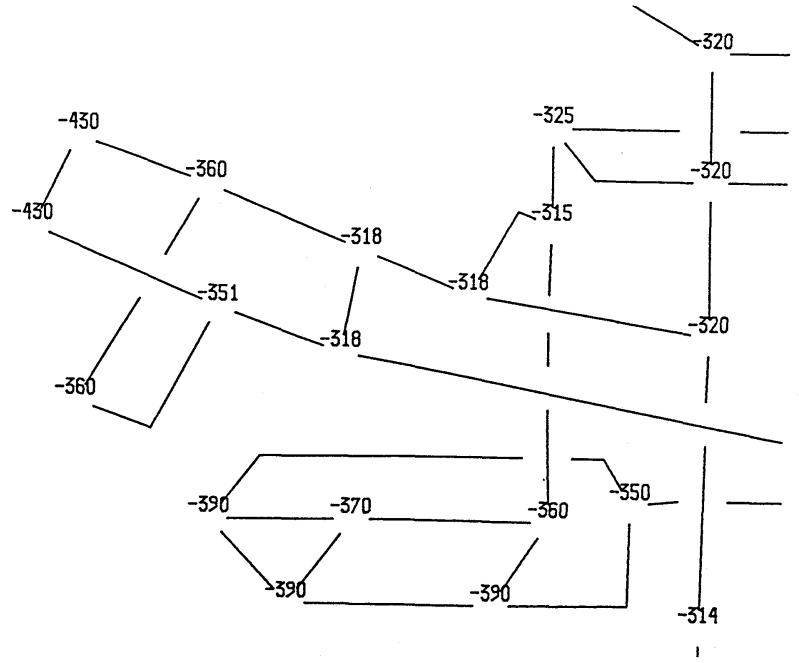

図 7 図 6 の通気網の深度分布 $(\mathrm{m})$

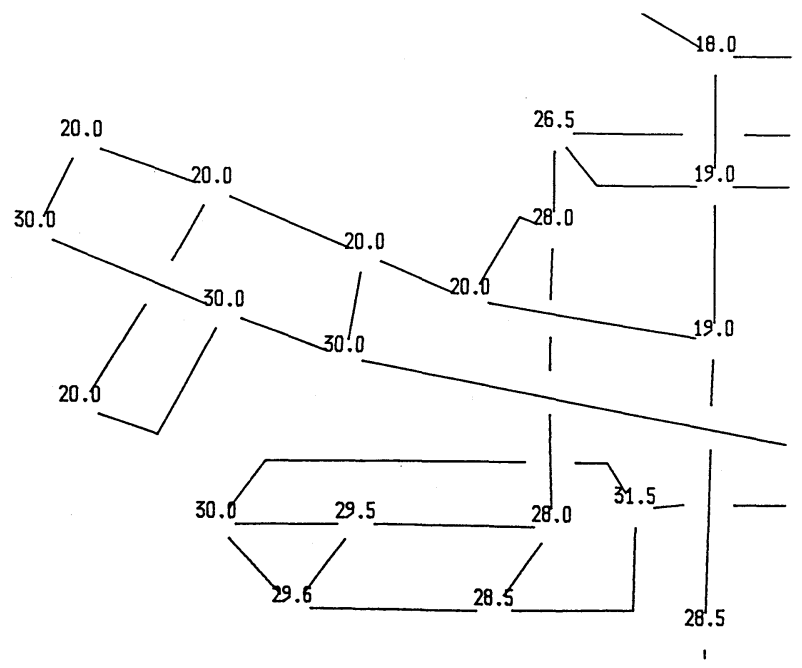

図8 図 6 の通気網の温度分布 $\left({ }^{\circ} \mathrm{C}\right)$
自然通気圧の方が支配的な通気圧として作用している場合がある。 図 6 に示寸ような通気網を考える。坑道の深度が図 7, 温度が 図8に示すようである場合に, この自然通気圧を考虑して風量を 求めた結果を図 $9 に$ 示す。ただし, 節点 215 付近以外の部分は紙面 の都合で省略している。同じ通気網で節点 $215,230,235$ の温度

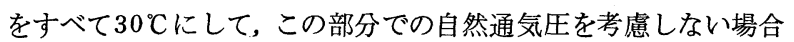
の解析結果を図 9 に[ ] 付きで示す。自然通気圧を考慮した場合 としない場合では, 節点 215 付近の坑道を流れる風量は全く異なる が, これ以外の風量はほとんど同じである。この原因は通気の上 り向きの部分の温度が下り向きの部分の温度よりも高いために, 自然通気圧が発生し, 通気を流しているためである。従って, 高 度差ならびに温度差が存在する通気網を解析する場合, 自然通気 圧を無視しては, 正確な風量を求めることができないことに注意 するべきである。

自然通気圧の影響によるこのような風量の差は, 通常の通気管 理においても重要であることはもちろんであるが, 非常時の通気 対策においても大きな問題となる。ここでは, 非常時に, 目抜き に設けられた風門を解放して通気の短絡を行なおうとする際の問 題について検討する。

坑道 215-221は目抜きに相当する坑道である。図 9 に示す風量 は，この目抜きの風門が閉じられている場合に相当する通気抵抗 （900ミュルグ）を用いている。この風門を開放した場合の風量分 布を図10に示す。同図にも自然通気圧を考慮した場合としない場 合の解析結果を示しているが，〔]付きの風量は自然通気圧を考 慮しない場合である。また, 目抜きの開放時の通気抵抗は 1 ミ ルグとしている。

自然通気圧を考慮した場合, 目抜きの風量は 28 から $93 \mathrm{~m}^{3} / \mathrm{min}$ に増加しただけであり，これより奥の坑道は，この目抜きよりも 通気抵抗が大きいにもかかからず $1421 \mathrm{~m}^{3} / \mathrm{min}$ もの風量が流れて おり, 開放する前の風量 1481 とほとんど変化がない。これは目抜 きを開放すれば通気が短絡してそれより奥の坑道へ流れる風量を かなり小さくできるという予想と異なるものである。この原因は もちろんこの部分の自然通気圧である。このような場合，爆発， 火災，突出などによって発生したガスが節点 215 より奥に侵入す

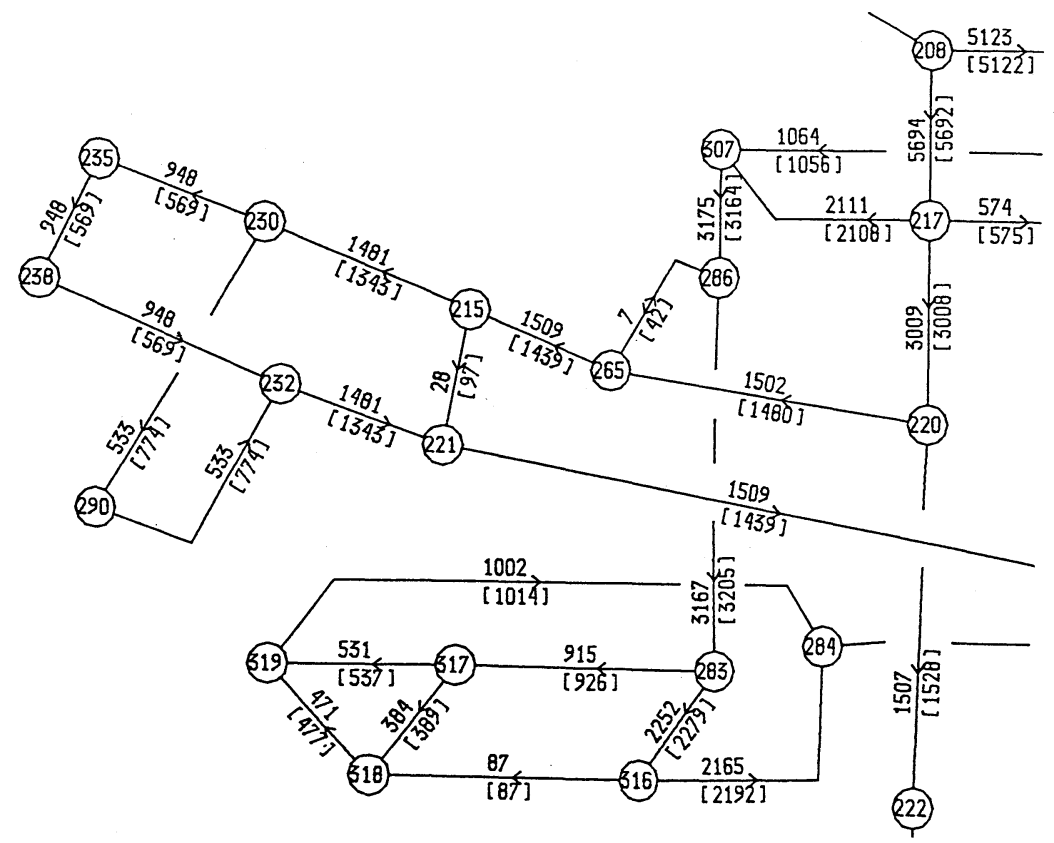

図9図6 の通気網の風量分布 $\left(\mathrm{m}^{3} / \mathrm{min}\right)$ [ ]内は自然通気圧を考慮しない場合の風量

資源・素材学会誌 $105 \quad$ （1989） No.7 


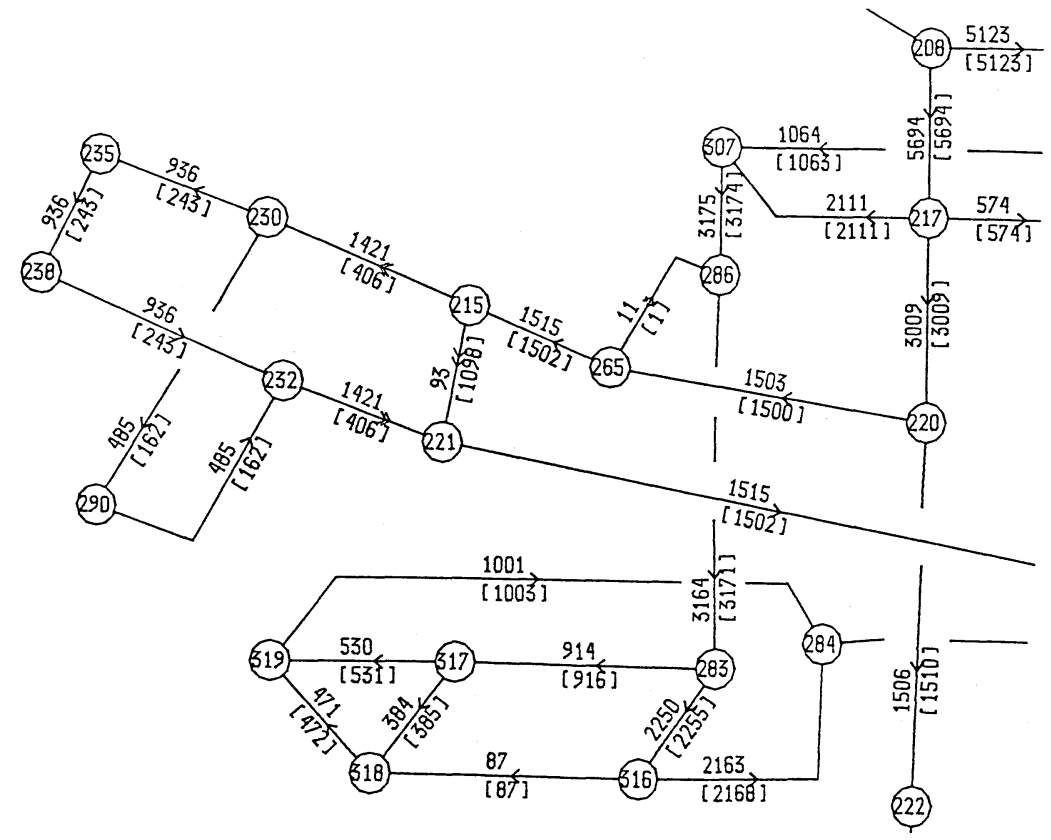

図10図 6 の通気網で, 坑道 215-221 開放した場合の風量分布 $\left(\mathrm{m}^{3} / \mathrm{min}\right)$ [ ]内は自然通気圧を考慮しない場合の風量

ることを防ぐ方法として，目抜きを開放することはほとんど効果 がなく，例えば坑道 215-230を遮断しなければならない。

自然通気圧を考慮しない場合, 目抜きの風量は 97 から $1098 \mathrm{~m}^{3} /$ minに增加し, これに対応して, これより奥の坑道に流れる風量 は 1343 から $406 \mathrm{~m}^{3} / \mathrm{min}$ に減少している。このような場合には， 目抜きを開放すれば，奥へ流れる風量をかなり減少できることを 示している。この結果は次の 2 つことを意味する。すなわち, 実際に温度差があるにもかかわらず，これを無視した解析を行な っているのであれば, 通気網解析によって得られる通気対策は実 際には全く役に立たない。また，実際にこのような温度差がない 場合には, 同図は正しい風量を示しており, この通気対策は有効 である。

\section{0. 結言}

本論文では節点解法による通気網解析の高速化について述べた。 本報で述べた方法を前報 ${ }^{7)}$ で述べた方法と併用した場合と，前報 で示した方法のみを用いた場合とを比較すると, 本報ならびに前 報で示した通気網では, 計算時間が $1 / 2$ から $1 / 4$ 程度に短縮され た。これは通気網が大きいほど顕著である。また，ファンの数が 多い, あるいは通気抵抗が小さい通気網等, 従来では収束に予想 以上の時間を要していた通気網でも計算時間を短縮できた。これ は他の通気網に対しても同様の効果を発揮できると考えられる。 実際，これまでに筆者らが手がけた全ての実際の鉱山の通気網に 対して計算時間の短縮が見られた。

計算時間を通気網解析を行なっている時間と考光, また, 解析 時間をある問題解決を開始してから結果を得るまでの時間と考え
れば, 実務においては, 解析時間が短いことも重要である。また， 通気網解析の結果は, 図面の形式で表現しなければならないが, 現在の通気網解析システムでは計算時間よりはプロッタで通気図 を書いている時間の方が長いのが普通である。このように通気網 解析はもはや大型計算機を用いる必要はほとんどなく, パーソナ ルコンピュータで十分解析可能である。なお，これらの成果は既 に筆者らの通気網解析システム「風丸」に取り入れられている。

$$
\text { 参考文 献 }
$$

1) $\mathrm{S} \cot t, \mathrm{D} . \mathrm{R}$. and Hinsley, F. B. : Colliery Engineering, $28,67 \sim 71,(1951)$

2）橋本交作・朝枝栄太郎・高橋一夫：日本鉱業会誌，82 [933]，8～ $16,(1966)$

3）岡 行俊·木山英郎 - 平松良雄：日本鉱業会誌，83[945]，1７, (1967)

4）平松良雄·天野勲三·大場重美: 日本鉱業会誌, 87 [1002], 623 $\sim 626,(1971)$

5) Gunther, J.: REVUE DE L' INDUSTRIE MINERALE, $49,797 \sim 802,(1967)$

6）冨長勇作·磯部俊郎 - Raman i, R. V. : 日本鉱業会誌, 100 [1152], 73 78, (1984)

7）井上雅弘・内野健一・野元知巳 : 日本鉱業会誌, 103 [1194], 493 497, (1987)

8) Bhamidipati, S. S., Procarione, J.A. : 2nd US Mine Ventilation Symposium (1985)

9）佐々木久郎・宮腰 宏：日本鉱業会誌，104 [1204]，353～357, (1987)

10）平松良雄: 坑内通気の理論と計算, $137 \sim 142$, 丸善出版

11) Howard L. Hartman: Mine Ventilation and Air Condition ing, 167 198, (1982) 